\title{
A Note on Wounded Calamites.
}

\author{
BY \\ M. C. STOPES, D.Sc., Ph.D. \\ Lecturer in Botany, Manchester University.
}

\section{With Plate XXIII and four Diagrams in the Text.}

$\Lambda^{N}$

interesting case of the formation of callus wood in a wounded Calamite is shortly described and figured by Seward ${ }^{1}$ in his 'Fossil Plants'. The stem, from which several sections were cut, is about $3 \mathrm{~mm}$. in diameter, and is, so far as I am aware, the only case in which such a formation has been noted.

Two specimens showing the healing of wounds in very much larger stems have recently come under my observation, and as in both cases the wound was deeper than in the Cambridge stem they show more complex arrangements in the healing tissues.

One of these specimens is represented by a series of three slides in the collection of the Manchester University Museum, Nos. R I00, R IOI, and $\mathrm{R}$ 102, and is entered in the catalogue as a 'branching stem.' The woody cylinder, which alone is preserved, is $35 \mathrm{~mm}$. in diameter, and shows, therefore, a considerable development of secondary tissue. This is seen in general view in Diagrams $I, 2$, and 3. The other specimen is a stem of about $25 \mathrm{~mm}$. in diameter, also without cortex, of which the two slides are in my possession. I obtained them from Mr. Lomax, labelled as coming through a node, but comparison with the first series makes it clear that they are also through a wound of a very similar nature (see Diagram 4).

In both these cases the wound was so deep as to pass right through the tissues to the pith, thus breaking through the vascular cylinder. As a result, the formation of new tissue curved round the open ends of the broken ring and formed a quantity of wood in the pith cavity in inverse orientation to the normal strands. In Professor Seward's specimen, which he kindly lent me for comparison with mine, the wound did not lie so deeply, but stopped short of the primary cylinder, leaving the bundle

1 A. C. Seward, Fossil Plants, vol. i, 1898, pp. 319, 320, Text-fig. 80. 
canals undisturbed, as can be seen in his diagram (loc. cit., Fig. 80). The callus wood in his case, therefore, though bending across to close up the wound, is simply formed in the normal direction. As the cylinder was

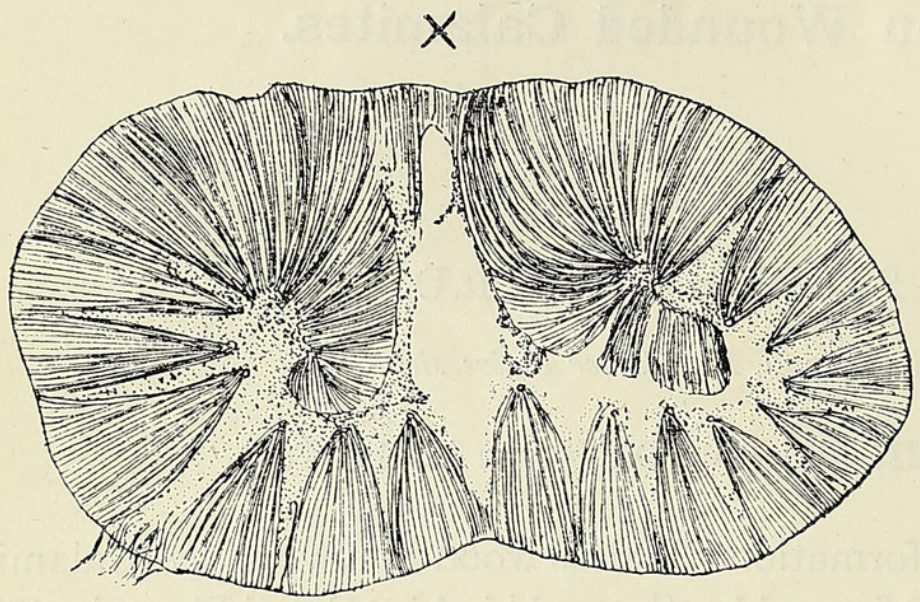

Diagram I. Trans. sect. of wounded Calamite, $\times 2$. Wound at $x$, externally just closed up. In the pith cavity on either side are the curved wedges of callus wood completely inrolled. R. I00, Manchester University Coll. not broken through, the edges could not inroll, thus making the case much simpler than in the larger stems with deeper wounds.

In the latter, as may be seen in Pl. XXIII, Fig. I, $c$, the woundcambium was very active in the neighbourhood of the injury, curving in and out round the primary bundles, adding new tissue where there was room for it. The injured primary strands, with small quantities of secondary tissue associated with them, have been cut off and isolated from the rest of the wood by this cambium band (see Pl. XXIII, Fig. I, $p$ ), and had evidently partly decayed while the rest of the stem was still vigorous, judging from the different states of preservation of the two tissues.

That there was a definite formation of inverted wood in addition to the callus wood curving round the edges may be

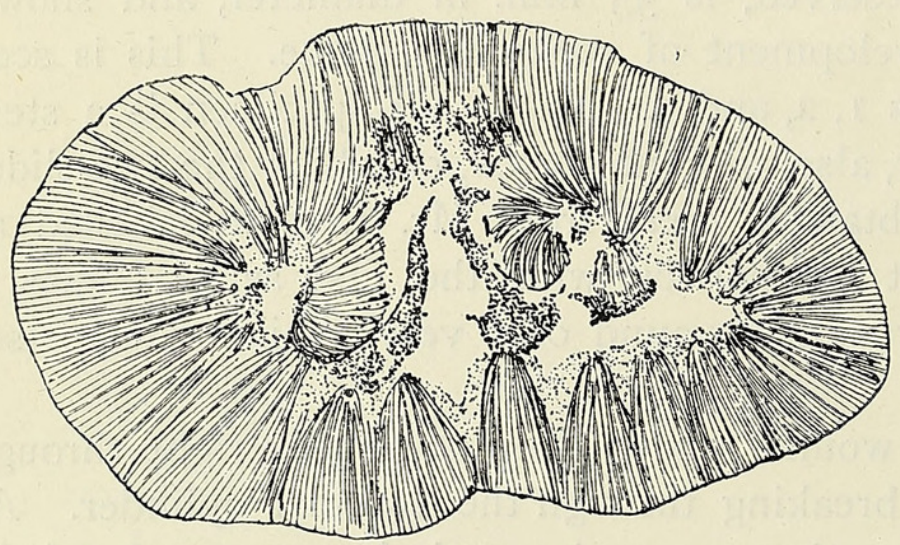

Diagram 2. Neighbouring sect. R. IOI. $\times 2$. Externally wound further closed, inrolled wedges of callus less developed. seen by the position of the cambium zone, which extends round the primary strands some distance beyond the actual woundgap. This cambium does not simply form a mass of new tissue, but tends to produce bundles facing the normal ones (see Pl. XXIII, Figs. I and 2, i). The inverted masses of

tissue are thinner-walled than the bulk of the woody elements, but are thickened and definitely pitted, as examination with the high power clearly reveals. Where the callus wood is cut obliquely it shows that some of the tracheides are very irregular and much curved. This has been described 
as occurring commonly just at the point of exit of branches in normal Calamite stems (see Williamson ${ }^{1}$, Fig. 28, Pl. XXI, and Fig. I 7, P1. XX), and is also a character of the callus wood of many plants, see Küster, p. $177^{2}$.

The exact shape of the wound is not to be determined from the small number of sections available, and may have extended for some distance down the stem, where it may not have closed completely; in those sections which we have, however, the wound was externally closed up, and the wood formed outside it (as in Diagram 3) is

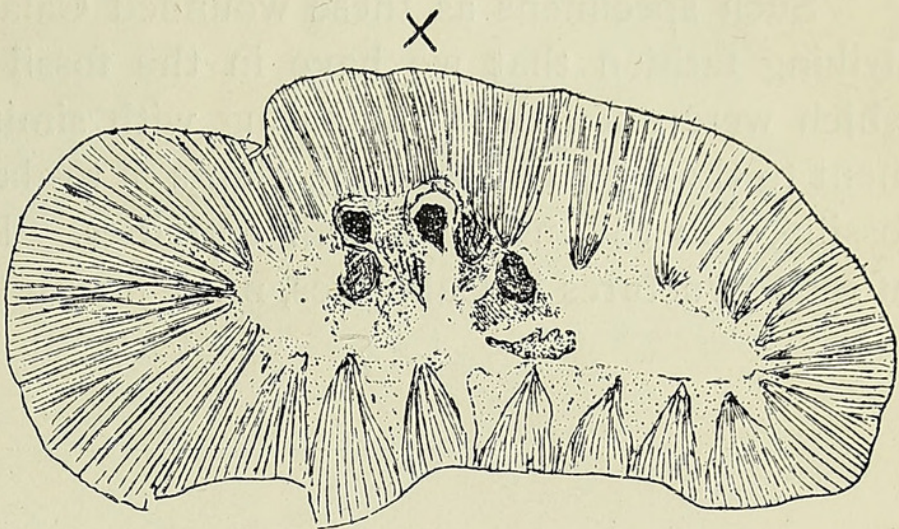

Diagram 3. Neighbouring sect. R. I02. $\times 2$. No inrolled wedges, groups of wood associated with primary bundles cut off by cambium, and inverted strands facing them in pith cavity. Cf. Fig. I, P1. XXIII. entirely normal in ap-

pearance. As the figures show, the total thickness of the normal secondary wood is greater on the injured than on the uninjured side.

The formation of inverted strands of wood in the pith is to be looked upon simply as a result of the stimulus of the wound, and the physical conditions and space opened out by the breaking of the vascular cylinder. It is hardly to be supposed that they are of phylogenetic importance, or in any way to be compared with the inverted strands in the Pteridosperms and Gymnosperms. They probably find a close analogy among the fossils in the inrolled secondary wood in a $L e p i-$

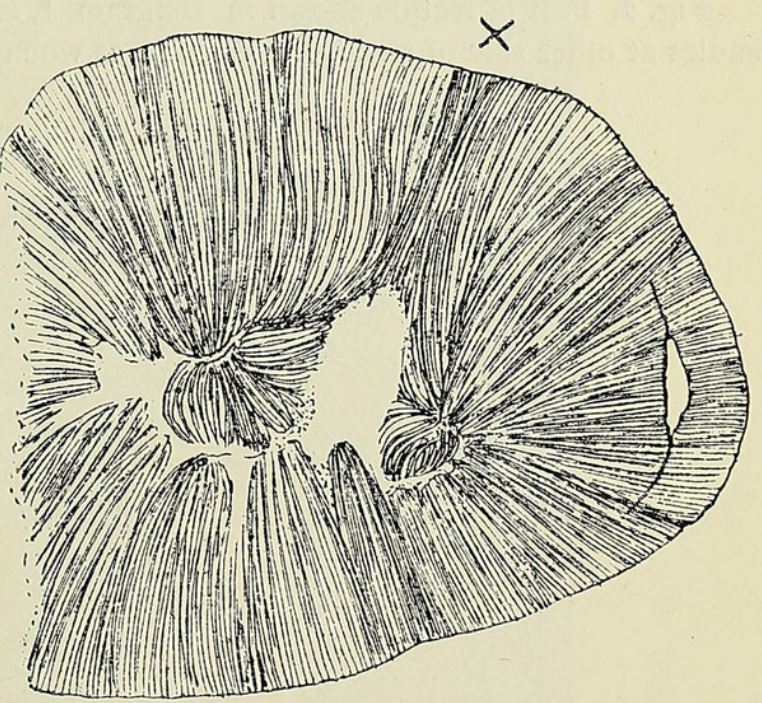

Diagram 4. Trans. sect. of second specimen. $\times 2$. Wound at $x$, externally closed, but showing in pith inrolled strands of wood. dodendron described and figured by Williamson ${ }^{3}$, p. 292, and Fig. 20, Pl. XLIII, in which the dichotomizing cylinder did not close up to form two complete rings as is usual,

1 W. C. Williamson, On the Organization of Fossil Plants, Pt. IX, Phil. Trans., I 878.

2 E. Küster, Pathologische Pflanzenanatomie, 1903.

${ }^{3}$ W. C. Williamson, On the Organization of the Fossil Plants of the Coal-Measures, III, Phil. Trans., 1872 . 
but each half remained open, and the secondary tissue inrolled in the pith and 'endeavoured to accomplish' the closure of the cylinders. Among recent plants, wounds and pathological conditions frequently lead to the formation of unusually orientated and abnormal wood ${ }^{1}$.

Such specimens as these wounded Calamites, reveal in a particularly striking fashion that we have in the fossil tissues the remains of plants which were once alive, combating with similar accidents in their environment to those which assail the plants of to-day, and were stricken down and fossilized in the midst of their activities. This, as well as the great rarity of such structures in Calamites, must justify the present short note.

\section{DESCRIPTION OF PLATE XXIII.}

Illustrating Miss Stopes's Paper on wounded Calamites.

Photos. by Mr. James Lomax.

Fig. I. Part of section shown in Diagram 3, enlarged. $\times$ I2. $p$, groups of primary bundles and associated secondary tissue cut off and isolated by $(c)$ cambium, which has produced $(a)$ additional tissue between the primary strands, and also $(i)$ inverted strands opposite them. Note the very wavy course of the cambium resulting from this.

Fig. 2. Part of section shown in Diagram 2, enlarged. $\times$ 18. $n$, normal wood. $n^{\prime}$, normal bundles at other side of stem. $x$, position of wound. $i$, inverted strands opposite primary bundles.

${ }^{1}$ P. Sorauer, Handb. d. Pflanzenkrankheiten, Pls. II, IV, \&cc. 
Annals of Botany.

Vol. XXI, Pl.XXIII c.
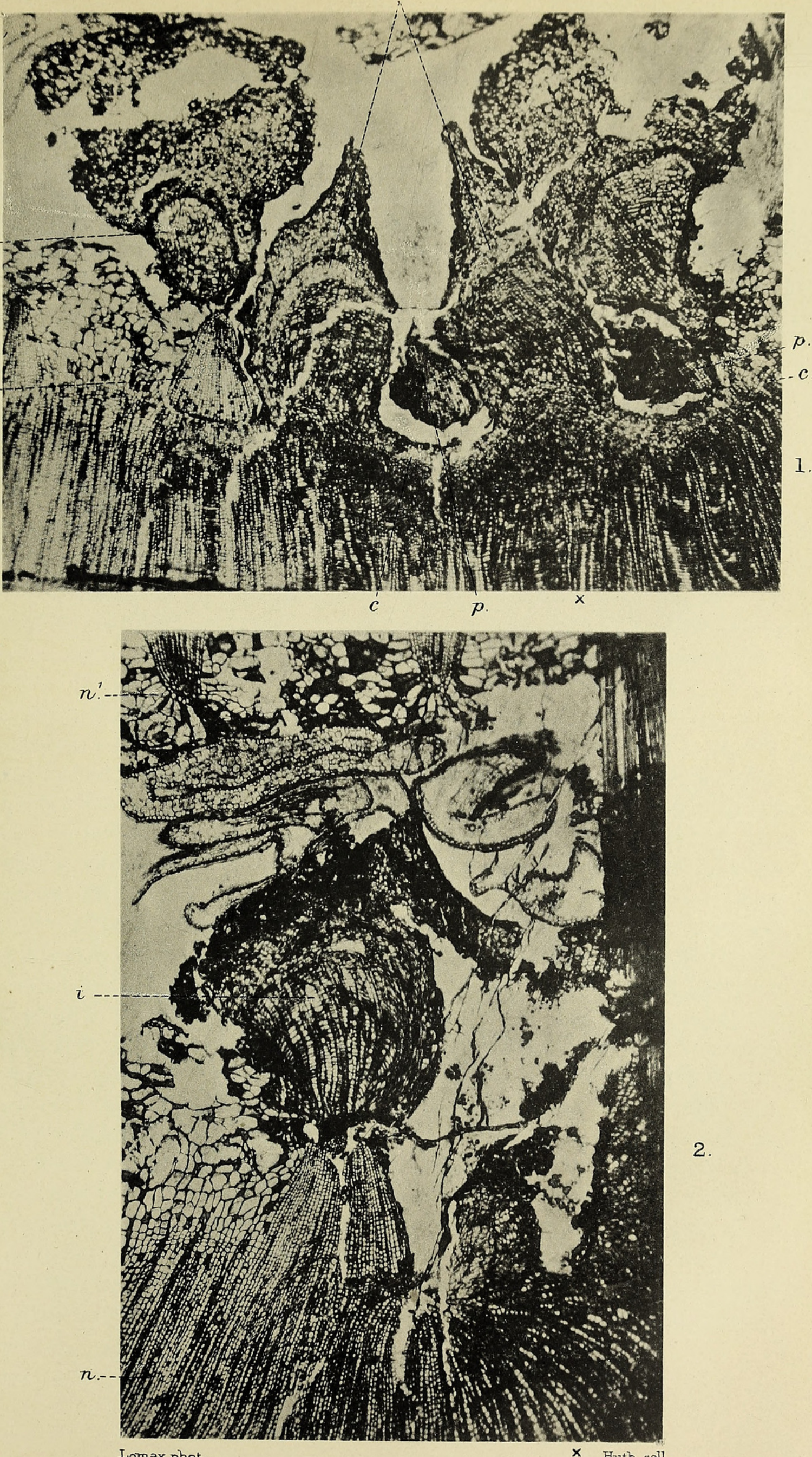


\section{$2 \mathrm{BHL}$ Biodiversity Heritage Library}

Stropes, M. C. 1907. "A note on wounded calamites." Annals of botany 21, 277-280. https://doi.org/10.1093/oxfordjournals.aob.a089133.

View This Item Online: https://www.biodiversitylibrary.org/item/235747

DOI: https://doi.org/10.1093/oxfordjournals.aob.a089133

Permalink: https://www.biodiversitylibrary.org/partpdf/318872

\section{Holding Institution}

Smithsonian Libraries

\section{Sponsored by}

Biodiversity Heritage Library

\section{Copyright \& Reuse}

Copyright Status: Not in copyright. The BHL knows of no copyright restrictions on this item.

This document was created from content at the Biodiversity Heritage Library, the world's largest open access digital library for biodiversity literature and archives. Visit BHL at https://www.biodiversitylibrary.org. 